\title{
Information Literacy Experience of Undergraduate Students during Their Involvement in the University Creativity Program
}

\author{
Heriyanto $^{1, *}$, Yanuar Yoga Prasetyawan ${ }^{1}$, Yuli Rohmiyati ${ }^{2}$ \\ ${ }^{1}$ Faculty of Humanities, Universitas Diponegoro, Semarang, Indonesia \\ ${ }^{2}$ Faculty of Information Science and Technology, Universiti Kebangsaan Malaysia, Selangor, Malaysia
}

Received June 16, 2020; Revised September 14, 2020; Accepted September 29, 2020

\section{Cite This Paper in the following Citation Styles}

(a): [1] Heriyanto, Yanuar Yoga Prasetyawan, Yuli Rohmiyati, "Information Literacy Experience of Undergraduate Students during Their Involvement in the University Creativity Program," Universal Journal of Educational Research, Vol. 8, No. 11B, pp. 5729 - 5734, 2020. DOI: 10.13189/ujer.2020.082207.

(b): Heriyanto, Yanuar Yoga Prasetyawan, Yuli Rohmiyati (2020). Information Literacy Experience of Undergraduate Students during Their Involvement in the University Creativity Program. Universal Journal of Educational Research, 8(11B), 5729 - 5734. DOI: 10.13189/ujer.2020.082207.

Copyright $(2020$ by authors, all rights reserved. Authors agree that this article remains permanently open access under the terms of the Creative Commons Attribution License 4.0 International License

\begin{abstract}
Indonesian universities have a long tradition of supporting their students in developing their innovative and creative ways of thinking during their times in university. One of the programs being continuously offered to the students is named student creativity program. It was initiated in 2001 to showcase students' creative and innovative works. This study presented undergraduate students' information literacy experience during their involvement in this program conducted by Diponegoro University, Indonesia. This research was based on the relational perspective of information literacy that emphasizes the relationship between people and information. Qualitative data were collected through semi-structured interviews with 15 undergraduate students from 8 different faculties. Thematic analysis was conducted to interpret various related aspects. Results revealed that the identified themes contributed to communities, brainstorming, and Googlization. All the themes illustrated the information literacy experience of undergraduate students as they contributed to the university creative program. This study provided new insights into students' creativity programs and information literacy as a basis for designing future research. Although the majority of studies in Indonesia have focused on the conception of information literacy from a behavioral perspective, this research offered different ways on understanding the conception of information literacy. This
\end{abstract}

research would be beneficial to university libraries in terms of enhancing their information literacy programs and faculties in terms of understanding how undergraduate students interact with information during their academic activities.

Keywords Information Literacy, Undergraduate Students, Student Creativity Program

\section{Introduction}

Indonesian universities have supported their students in developing their innovative and creative ways of thinking during their school years. One of the programs being continuously offered to students is named student creativity program. This program was initiated in 2001 to showcase students' creative and innovative works. Students from various countries normally join the program and compete with one another by showing their innovative ways on solving current global issues, such as environmental issues, food, health, gender, and other issues introduced by UNESCO's Sustainable Development Goals. Students who are interested in the program can select one of the three programs designed by the Ministry: research, community works, and entrepreneurships. The program is 
competitive yet rewarding; so many students from different Indonesian universities join the program. They are the ones who win competitions in their universities. Winners from each have the opportunity to join the national competition called the National Scientific Week. In this phase, every group of students compete with the other groups from universities in Indonesia by presenting their innovative programs based on their selected program.

Students can select research, community works, or entrepreneurship programs. Lecturers from different fields choose to guide the students in preparing their proposals that are then submitted to the university. Only the selected proposals are funded by the Diponegoro University so that they can conduct their proposed activities and have a higher chance of going to the national competition.

The interested students form a group and start writing a proposal. They work with their supervisor in proposal preparation. This research aims to explore the experience of students using information to prepare their proposal and participate in the student creativity program.

Diponegoro University, one of the state universities in Central Java, annually participates in the competition. It prepares their students on planning, designing, and researching current issues that are relevant to the competition. Students who join the program then prepare themselves to look for specific issues related to their field of study. Many students are from different study backgrounds, so seeing how these undergraduate students find ways on selecting issues and recommending solutions is interesting.

The emergence of scholarly discourses on the engagement of undergraduate students with information and the way libraries enable such an engagement has become a significant issue. These scholarly discussions have transitioned from a simplistic form to a more complex understanding of the information world and information behavior [1]. Initially, the discussions focus on resource use, library use, library skill instruction, information access, and general use; now, they include everyday life experiences of people as information users. A university student is considered a challenging profession. It requires students to deal with some amounts of works during their times in universities. Academic works, which are commonly known as assignments, may come in different forms, such as essays. To do these works, students should have good information skills that enable them to understand the topic of their assignment and solve related problems. These skills include the knowledge on locating information and understanding the best strategies to acquire relevant information through available information sources. Online information search strategies are among the critical variables in effective and efficient information skills. A previous research showed that lecturers and students experience issues in acquiring, accessing, and using information online and offline [2]. Such issues may be attributed to the lack of technical competencies and infrastructural problems [3]. Technical competencies refer to a student's ability to locate and apply online information search strategies.

The large amount of information and the availability of information resources are understood well by many students. Current students are known as a generation that lives and grows with the development of Internet and its rich application. They are known as the digital native generation. However, being considered as a digital native generation has left them with a question about their ability to complete their tasks in universities by using different sources of available information. This study investigated how students in one of the faculties in Diponegoro University find and use information during their study.

Our findings contributed to the scholarly discourse about people's information literacy experience, especially the undergraduate students' experience, as a basis for designing future research. The discovery added knowledge that involved the theoretical understanding of undergraduate students who use information resources as part of their broadened information world. The contribution also supported the practical aspect; that is, Indonesian university libraries could utilize our findings to guide the development of library instruction programs and ensure that the programs genuinely meet the information literacy needs of this group of students.

\section{Literature Review}

Indonesian universities have a long history of supporting their undergraduate students in various activities. Conducting an event aims to encourage students to have innovative, creative, and entrepreneurship programs. Creativity focuses on the generations of new ideas or associations between existing concepts, while innovation involves the implementation of ideas in specific contexts. Entrepreneurship covers the identification and capturing of opportunities of useful outcomes in which people's needs can be satisfied or solutions can be developed [4]. Universities value the student creativity program because students learn about soft skills, such as being independent, creative, innovative, and problem solvers through their involvement in the program.

Information is important for students to contribute to university programs, so students may have used different sources of information that they believe is accurate, reliable, and easy to use. Current undergraduate students are considered the digital native generation. This generation was born in the last decade of the 20th century and grew up surrounded by smartphones, video games, and the Internet. Studies have shown that the digital native generation has developed a set of features that complies with the world around them. Some of these features include accessing information rapidly, multitasking, preference for graphics over textual content, and being connected to 
networks [3]. Therefore, digital natives think and learn in ways that differ from other generations.

Undergraduate students require a quick access to reliable sources that are easily read without concentrating for long periods [5]. They are also a part of the technology-savvy generation that possesses and benefits from social connections created by social media [6]. Social media has become increasingly popular for undergraduate students, and most of them spend time using social media to communicate, share information, learn, and engage in their leisure time [7]. They immerse in a digital world that creates constant stimulation and satisfies the need of being connected. Digital native students have different levels of technological knowledge and use technology in different ways [8]. Even though digital natives prefer social media for their personal lives, they do not necessarily use social media for their academic needs. For instance, when they face the need of information, their preferences are Google.com and Wikipedia [9]. Students feel more comfortable with these two sources because Google and Wikipedia are easy to use. However, further research has suggested that Google and Wikipedia are helpful for students when they are familiar with their topic. Those who are still looking for the appropriate topic search information from the library website. Therefore, undergraduate students may experience difficulties in locating information related to their academic life.

Information search is a complex process that embodies defining, seeking, processing, organizing, and eventually synthesizing information. Understanding how information is used in learning and university context is based on theoretical perspectives influenced by the field of information behavior and information literacy [10]. Information behavior perspectives involve the utilization of information services to improve information literacy, while information literacy covers three different perspectives on understanding how information is experienced [11]. Bruce [12] introduced one of the perspectives named relational information literacy; it focuses on various ways people relate to information and interact with elements of their informational worlds [11]. In this perspective, information literacy is not considered a set of skills; instead, it is defined as the experience of information users engaging with information. Number of studies investigating students' information literacy using relational perspective has been conducted. Maybee [22] observed undergraduate students' information literacy, Boon, Johnston and Webber [23] who examined English faculty academics' experiences of information literacy, and Williams and Wavell [24] in a study on the experiences of information literacy among secondary school teachers.

Based on the relational perspective, this study explored the information literacy experience of undergraduate students who joined the student creativity program. It revealed how students engaged with their information world during their participation in the program.

\section{Method}

This qualitative study addressed the research question on how undergraduate students experience information literacy during their involvement in a university program named student creativity program to explore the undergraduate students' information literacy experience in the program conducted by Diponegoro University. Data were collected through semi-structured interviews with 15 undergraduate students from 8 different faculties. The study population was not limited to specific disciplines because this study aimed to investigate the nature of information literacy experiences for different groups of students (e.g., health, business, or engineering). Therefore, for the purpose of this study, students from all the faculties were targeted for data collection.

The recruited participants were students who joined university innovative programs from the last 2 years. They could be students who were in their third or fifth year in the program. The participants were recruited in two ways. First, the main researchers contacted the office of the student creativity program to obtain the list of students who joined the innovative program in the last 2 years. This duration was chosen because some students from the last year event were unable to participate in the study. Among the students who were contacted, 15 agreed to be interviewed. The list of the participants' faculties is presented in Table 1.

Table 1. List of students' faculties that participated in the study

\begin{tabular}{|c|c|}
\hline Faculties & $\begin{array}{c}\text { Number of students who } \\
\text { participated }\end{array}$ \\
\hline Humanities & 3 \\
Law & 1 \\
Fisheries and Marine Science & 2 \\
Naval Architecture & 2 \\
Social and Politics & 2 \\
Mathematics and Science & 2 \\
Health & 2 \\
Psychology & 1 \\
\hline
\end{tabular}

A semi-structured interview is considered appropriate for collecting data in this research because it aimed to answer "how" questions. It enables the researchers to uncover the experiences of the participants. Therefore, the two parties should have a "theme of mutual interest" [13]. The interviews were conducted to reveal the understanding of the information literacy experience of the undergraduate students during their involvement in the university program.

In accordance with established qualitative practice, the collected data were analyzed by employing thematic analysis. It is a method that can be applied to identify and examine patterns or themes within the data that are considered to be important for the descriptions of the phenomenon of a study [14]. Thematic analysis was conducted in this study to interpret various aspects from 
the topic being studied by "encoding" the obtained qualitative data [15]. The analysis processes consisted of three phases, namely, familiarizing data, generating codes, and identifying themes. In the first phase, interview transcripts were used to familiarize with the data and read two to three times to thoroughly understand the data. After each transcript was read, a summary was written to describe the reflection of the researchers about the data in the transcripts. In the second phase, codes were generated for the data. These codes identified the feature of the data that appeared relevant to the phenomenon being studied. In the third phase, themes were identified. Themes refer to patterns in data that explain and organize the aspects of the phenomenon derived from the data. The codes generated in the previous phase were reviewed and examined multiple times against the main research question, i.e., how was the students' information literacy experience during their involvement in the university creative program? The identified themes are explained in Section 4.

\section{Findings and Discussions}

The 15 participants interviewed represented different faculties in Diponegoro University. Most of them were engineering students, while the others were law, health, and mathematics students. They participated in three student creativity programs, namely, research, innovation, and entrepreneurship. The interview findings were arranged thematically to illustrate the information literacy experience of the undergraduate students who joined the student creativity program.

\subsection{Contributing to the Community}

Contributing to the community is the first theme illustrating the experience of students' involvement in the student creativity program. This theme captures students' awareness about current issues globally and locally. Contributing to community draws any effort of the participants to make enhance the communities around them. This improvement is evident in the products made for this creativity program. For example, Taufik, the first participant who is an electronic engineering student created a drone specifically designed for collecting data in areas affected by natural disasters throughout Indonesia. According to Taufik, the drone could be operated in remote areas to capture data that can be used by the government or any other bodies for sending food and other materials for the victims.

"During natural disasters, we need food and water to help the injured ones. We also need accurate data about what is happening, how many victims, and how we can deliver the aids to those in need (Taufik)."

Two other participants, Rizka and Tifa, participated in 2018 and joined the entrepreneurship scheme. Rizka was a physics student, and Tifa was an environmental engineering student. In this project, Rizka created a tooth whitening product made of environmentally friendly carbon. It was produced by using a nanoparticle that could be safe for daily use because it was composed of organic materials.

Tifa offered new ways to produce paper. Instead of using wood, Tifa made paper with water hyacinth weeds. The finished product was used for teaching elementary students in her local area.

Another participant was Tria who was enrolled in the research scheme. As a law student, Tria's research proposal aimed to investigate the ways on protecting home workers' rights.

The participants aimed to help solve real-world problems by creating their products. This phenomenon suggested that these students could have self-awareness on current issues and have the initiative to help. The awareness of these students about current issues and their efforts to respond to such issues showed their information literacy during their involvement with the student creativity program. Moreover, being a student and being busy with their studies do not necessarily make them ignorant about current events. Instead, their works indicated that they are aware and able to contribute to the betterment of people's lives. This finding supports Corodeanu [16], who mentioned that Gen Y is tolerant and loyal and can contribute to the society.

\subsection{Brainstorming}

Brainstorming is an aspect of participants' experiences of their involvement in the student creativity program as part of their information literacy. This theme elucidates their preferences and insights into the program before they join. According to the participants, in relation to their contribution to the program, they first looked at ideas that could help them define what they could do for the program. Most of them indicated that they used Instagram, Facebook, and YouTube to search for any information about current issues related to environments and health issues.

The number of participants indicated that they used social media platforms to find relevant information and obtain some useful ideas for the student creativity program. Taufik used Instagram and YouTube mainly because of the visualization of any other relevant projects. Most of the participants were fully aware that implementing what they have learned from their classroom into real-life situations was challenging, and they believed that they would obtain such information through social media platforms. According to Pînzaru and Miltan [17], digital native students are Internet savvy, eager to learn, selective, and able to consume relevant information fast. Social media is a technology that may be relevant with the Gen Y characteristics because it can help digital native users in terms of their need for autonomy, achievement, affiliation, and belonging [18].

After the participants obtained ideas and knew what they 
would be doing for the student creativity program, they communicated their ideas to their peers via ResearchGate. In this social media site, they upload their proposal and obtain some other similar articles. Rizka commented that she commonly meets other students online through a discussion forum and discusses their research proposal. Rizka found that ResearchGate is useful for developing what she already knows about the topic, but Instagram and YouTube are useful for obtaining ideas about the research. Therefore, when students search for information, they conduct two separate activities, starting and networking [19]. Networking was implemented by the participants by "following" or "subscribing" through YouTube and Facebook and by joining the online discussion in ResearchGate.

The information searching behavior presented by the participants showed their information literacy during their involvement in the student creativity program. Other studies have found that Google and academic databases [20] are the students' preference during information search; the participants indicated that they have different perspectives about information resources. However, Castillo de Mesa, Gómez-Jacinto, López Peláez, and Erro-Garcés [21] indicated that social media is used by university students not only for engaging with friends and family but also for searching information related to their study.

\subsection{Googlization}

Googlization is an aspect of the participants' involvement in the student creativity program as a part of their information literacy. The participants' information literacy includes Google as they use Google to search for explanations about information they found earlier through social media. Some participants commented that they commonly use Google to find explanations about any terms they found from Instagram or other social media platforms. Most of them use Google to clarify definitions. The interactivity between students and Google illustrates that Google as a search engine has become the main information source. Their previous experience of using Google and the ease of use of this search engine have become a substantial aspect that encourages most of the participants to use Google. This information is relevant in the research of López-Fitzsimmons and Nagra [5], who indicated that Google is easier to use and more straightforward than library databases. However, this study confirmed the findings of Castillo de Mesa, Gómez-Jacinto, López Peláez, and Erro-Garcés [21], who found that Google and social media are also used by undergraduate students for educational purposes.

\section{Conclusions}

The undergraduate students who participated in this study are considered a part of the digital native generation.
They were born during the advanced technological development. They use mobile technology, such as smartphones, during their daily activities and academic purposes. The themes generated in this study illustrated the undergraduate students' information literacy when they contributed to the student creativity program conducted by the Diponegoro University. The first theme, which contributed to the communities, captured the motivations of the participants. Most of them confirmed that they joined the program to respond to real-world problems faced by their communities. They became aware of current global events through news distributed in social media channels. The second theme was brainstorming. Through this theme, the participants could find information about current events from social media channels, such as Instagram and YouTube, to generate ideas. Brainstorming illustrated the information literacy of the participants by showing how they used social media for brainstorm ideas. The last theme was Googlization, which captured the information literacy of the participants by describing how they relied on their information selection through Google.

This research is useful for libraries to develop their information literacy programs for their students and for faculties to understand how undergraduate students relate their information needs to their information world. However, this research focused on undergraduate students who joined the student creativity program. Future research should investigate the information literacy experience of students in different contexts to provide different insights into the information literacy discourse.

\section{Acknowledgments}

This research is a collaboration project that relies on multiple individuals. We are grateful to all the participants who were interviewed and the Research and Services Unit of Diponegoro University who provided research administration assistance. This study was conducted under the Development and Implementation Research scheme funded by Diponegoro University.

\section{REFERENCES}

[1] C. Bruce, K. Davis, H. Hughes, H. Partridge, and I. Stoodley, Information Experience: Contemporary Perspective. UK: Emerald Group Publishing Limited, 2015.

[2] E. Kuiper, M. Volman, and J. Terwel, "Integrating Critical Web Skills and Content Knowledge: Development and Evaluation of 5th Grade Educational Program," Comput. Hum. Behav., vol. 24, no. 3, pp. 666-692, 2008.

[3] A. N. Çoklar, N. D. Yaman, and I. K. Yurdakul, "Information Literacy and Digital Nativity as Determinants of Online Information Search Strategies," Comput. Hum. 
Behav., vol. 70, pp. 1-9, 2017.

[4] R. N. Dino, "Crossing Boundaries: Toward Integrating Creativity, Innovation, and Entrepreneurship Research Through Practice," Psychol. Aesthetics, Creat. Arts, vol. 9, no. 2, pp. 139-146, 2015.

[5] B. M. López-Fitzsimmons and K. A. Nagra, "Google vs. Library Databases: Engaging Twenty-First Century Undergraduate Students in Critical Thinking," J. Electron. Resour. Librariansh, vol. 31, no. 4, pp. 219-231, 2019.

[6] A. Daigle, "Social Media and Professional Boundaries in Undergraduate Nursing Students," J. Prof. Nurs., vol. 36, no. 2, no. 2, 20-23, 2020.

[7] B. Stvilia and L. Gibradze, "Examining Undergraduate Students' Priorities for Academic Library Services and Social Media Communication," J. Acad. Librariansh., vol. 43, no. 3, pp. 257-262, 2017.

[8] D. Popescul and M. Georgescu, "Generation Y Student in Social Media: What Do We Know About Them?", BRAIN Broad Res. Artif. Intell. Neurosci., vol. 6, no. 3-4, pp. 74-81, 2015.

[9] S. Komissarov and J. Murray, "Factors That Influence Undergraduate Information-Seeking Behavior and Opportunities for Student Success," J. Acad. Librariansh, vol. 42, no. 4, pp. 423-429, 2016.

[10] F. Q. Miller, "Experiencing Information Use for Early Career Academics' Learning: A Knowledge Ecosystem Model," J. Doc., vol. 71, no. 6, pp. 1228-1249, 2015.

[11] Heriyanto, Understanding How Australian Researchers Experience Open Access as Part of Their Information Literacy, Queensland University of Technology, 2018.

[12] C. Bruce, Seven Faces of Information Literacy. Adelaide: AUSLIBPress, 1997.

[13] S. Brinkmann and S. Kvale, "Doing Interviews," in The SAGE Qualitative Research Kit, London: SAGE Publications, 2017.

[14] H. Heriyanto, "Thematic Analysis sebagai Metode Menganalisa Data untuk Penelitian Kualitatif", Anuva, vol. 2, no. 3, p. 317, Nov. 2018.

[15] V. Braun and V. Clarke, "Demonstrating Rigor in Thematic
Analysis: A Hybrid Approach of Inductive and Deductive Coding and Theme Development," Int. J. Qual. Methods, vol. 5, no. 1, pp. 80-92, 2006.

[16] D.T. A. Corodeanu, "Consumer's Protection from the Generation Y's Perspective. A Research Based on Scenarios," Procedia Econ. Fin., vol. 20, no. 15, pp. 8-18, 2015.

[17] F. Pînzaru and A. Miltan, "Generation Y Students: Using Facebook for Communicating with University Staff and Professors," Manag. Dyn. Knowl. Econ., vol. 1, no. 2, pp. 221-239, 2013.

[18] E. A. Aygul and E. Eyubogli, "Generation Y Consumers in Turkey: Are They Really Social Media Nerds or Pretend to Be?" in 11th International Marketing Trends Congress, 2013.

[19] S. R. Fitzgerald, Information Seeking of Scholars in the Field of Higher Education by Submitted to Michigan State University in Partial Fulfillment of the Requirements for the Degree of Higher, Adult, and Lifelong Education-Doctor of Philosophy, 2017.

[20] S. Thomas, E. Tewell, and G. Willson, "Where Students Start and What They Do When They Get Stuck: A Qualitative Inquiry into Academic Information-Seeking and Help-Seeking Practices," J. Acad. Librariansh., vol. 43, no. 3, pp. 224-231, 2017.

[21] J. Castillo de Mesa, L. Gómez-Jacinto, A. López Peláez, and A. Erro-Garcés, "Social Networking Sites and Youth Transition: The Use of Facebook and Personal Well-Being of Social Work Young Graduates," Front. Psychol., vol. 11, pp. 230, 2020.

[22] C. Maybee, "Undergraduate perceptions of information use: The basis for creating user-centered student information literacy instruction," The Journal of Academic Librarianship., vol. 32, no. 1, pp. 79-85, 2006.

[23] S. Boon, B. Johnston, and S. Webber, “A phenomenographic study of English faculty's conceptions of information literacy," Journal of Documentation, vol. 63, no. 2, pp. $204-$ 228, 2007.

[24] D. A. Williams, and C. Wavell, "Secondary School Teachers' Conceptions of Student Information Literacy," Journal of Librarianship and Information Science, vol. 39, no. 4, pp. 199- 212, 2007. 